\title{
Metode FSN Analysis Dan Implementasinya Pada Desain Sistem Informasi Pergudangan
}

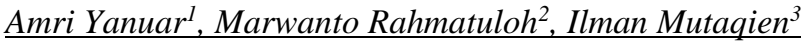 \\ Logistik Bisnis, Politeknik Pos Indonesia ${ }^{1}$ \\ Teknik Informatika, Politeknik Pos Indonesia ${ }^{2}$ \\ Sistem Informasi Manajemen Bisnis, STMIK LIKMI Bandung ${ }^{3}$ \\ Jl. Sariasih No. 54 Bandung, Indonesia ${ }^{1,2}$ \\ Jl. Ir. H. Juanda No.96, Lebakgede, Kec. Coblong, Kota Bandung, Indonesia ${ }^{3}$ \\ amriyanuar@poltekpos.ac.id ${ }^{1}$,mrahmatuloh@poltekpos.ac.id ${ }^{2}$,lemondaba@gmail.com ${ }^{3}$
}

\begin{abstract}
There are some activities inside the warehouse operation that is related to each other, namely; receiving, storage, and picking. These activities that usually called as inbound and outbound has to be done in a short period of time and reduce the number of error with the result that the flow of entry and exit of products within the warehouse will not be hindered. Several problems which usually appears to interfere the flow of goods inside the warehouse, among these are; bottle neck at the receiving area, time consuming when searching products, and approximately $70 \%$ time picking order process under standard time. Those problem occurred due to product management in the warehouse either conducted manually, or have not equipped yet by information system. In order to minimize error that would be able to hampered flow of products (in/out), the objectives of this research is to design the information system that could help warehouse operation in order to minimizing an error used FSN Analysis approached. The yield of this research products could be classified based on categories fast moving, slow moving, and non-moving.
\end{abstract}

Keywords: fsn analysis, warehousing, management information system, warehouse management, warehouse management system

\begin{abstract}
Abstrak
Operasional gudang memiliki berbagai aktivitas inti yang saling berkaitan satu dengan yang lainnya, seperti aktivitas receiving, storage, dan picking. Aktivitas inti ini atau yang biasa disebut inbound dan outbound harus dikerjakan dalam waktu yang singkat dan meminimalisir tingkat kesalahan agar tidak mengganggu keberlangsungan alur masuk dan keluarnya barang di gudang. Beberapa hal yang dapat mengganggu aliran barang di gudang di antaranya adalah terjadinya bottle neck di area receiving, waktu proses pencarian barang yang lama, dan $70 \%$ waktu proses order picking di bawah waktu standar. Permasalahan-permasalahan ini terjadi salah satunya dikarenakan pengelolaan barang di gudang masih manual atau belum menggunakan sistem informasi. Tujuan dari penelitian ini adalah merancang sistem informasi untuk membantu operasional gudang guna meminimalisir kesalahan-kesalahan yang dapat mengganggu aliran masuka dan keluarnya barang dari gudang, dengan menggunakan pendekatan FSN Analysis. Hasil dari pengolahan data menggunakan FSN Analysis ini, dapat membantu dalam mengetahui produk-produk yang masuk kedalam kategori fast moving, slow moving, dan non-moving.
\end{abstract}

Kata Kunci: fsn analysis, pergudangan, sistem informasi manajemen, manajemen pergudangan, sistem informasi gudang

\section{Pendahuluan}

Salah satu fasilitas khusus dalam kegiatan logistik dan supply chain management adalah gudang yang memiliki fungsi tetap untuk menyimpan berbagai jenis produk seperti raw material, WIP, dan finished goods. Fungsi gudang yang bersifat tetap ini terdiri dari berbagai aktivitas inti seperti; receiving, storage, dan picking, dimana aktivitas inti ini sangat berperan penting terhadap keberlangsungan proses kegiatan inbound dan outbound yang harus dilakukan dalam waktu proses yang pendek namun dengan tingkat kesalahan yang kecil. Tujuan utama dari gudang adalah mengelola pergerakan dan penyimpanan barang secara efisien dengan mengoptimalkan penggunaan tempat yang ada dan mengetahui secara spesifik dimana barang akan disimpan setiap saat [1]. Jika dilihat dari masing-masing aktivitas gudang yang dijalankan, serangkaian kegiatan aktivitas pergudangan memiliki keterkaitan satu dengan yang lainnya. Apabila dalam salah satu aktivitas mengalami ketidaksesuaian, hal ini dapat mempengaruhi aktivitas selanjutnya. Storage assignment merupakan salah satu aktivitas operasional gudang yang membutuhkan usaha lebih dalam meningkatkan efisiensi operasional gudang [2]. 
Masalah yang dihadapi dalam pergudangan diantaranya; terjadinya bottle neck di area receiving dikarenakan pencatatan deskripsi produk yang tidak lengkap, waktu proses pencarian barang yang panjang akibat miss bin location, dan kesalahan identifikasi dan informasi penyimpanan menyebabkan keterlambatan proses muat karena pencarian lokasi barang yang lama, dimana kasus ini juga diangkat oleh [3]. Permasalahan lainnya, proses order terhambat karena produk yang dibutuhkan masih menumpuk di stagging area dikarenakan produk masih menunggu untuk dilakukan put away. Sedangkan masalah yang umum dihadapi oleh gudang adalah penumpukan barang di area penyimpanan yang disebabkan oleh penerimaan barang secara random tanpa memperhatikan kategori produk, $70 \%$ waktu proses order picking di bawah waktu standar dikarenakan penempatan produk secara random [4]. Selain itu, pengolahan data barang di gudang belum optimal dikarenakan masih manual dan baru sebatas pada penggunaan aplikasi Microsoft excel, hingga menyebabkan penyampaian informasi belum bisa disajikan dengan cepat dan akurat [5]. Permasalahan umum lainnya yaitu transaksi tidak dapat dilihat karena tidak tercatat secara detail dikarenakan belum adanya program yang mampu merekam dan mencatat data keluar masuk barang di gudang[6].

Melihat dari beberapa permasalahan yang disebutkan di atas, diperlukan upaya yang harus dilakukan dalam meminimalisir kesalahan-kesalahan yang terjadi pada setiap aktivitas, salah satunya dengan sistem informasi. Sistem informasi memiliki peran penting dalam mencapai keunggulan logistik, berbagai perusahaan yang dihadapi dengan proses pergudangan secara kompleks telah menerapkan Warehouse Management System [7]. Permasalahan pergudangan dapat diatasi dengan merancang aplikasi proses pencarian dan penempatan terkait pengambilan barang jadi. Sehingga, sistem informasi diharapkan dapat membantu stock keeper dalam aktivitas penerimaan dan penyimpanan [3]. Penulis lain menambahkan Warehouse Management System dapat memberikan solusi terhadap permasalahan terkait ketersediaan informasi yang tidak lengkap atau disebut dengan "partial information availability" yang didalamnya terkait kurangnya visibilitas karakteristik dari persediaan (bobot, volume, dan konversi setiap stock keeping unit) [8].

Oleh karena itu, penelitian ini membuat rancang bangun sistem informasi penerimaan dan penyimpanan barang di gudang berupa prototype system dengan menerapkan pendekatan FSN (fast, slow, and nonmoving) Analysis untuk meminimalisir kesalahan-kesalahan yang terjadi pada aktivitas penerimaan dan penyimpanan pada studi kasus gudang barang jadi. Pendekatan ini sejalan dengan penelitian yang menerapkan pendekatan FSN Analysis untuk kegiatan penyimpanan barang di gudang, pendekatan ini digunakan untuk menentukan lokasi penyimpanan barang berdasarkan tingkat popularitas item yang dikategorikan pada fast moving, slow moving, dan non-moving untuk mengawali perencanaan penentuan lokasi (bin location) yang belum dilakukan pada penelitian terdahulu [9].

\section{Metodologi}

Pada penelitian ini metode pelaksanaannya dilakukan melalui penelitian pendahuluan melalui observasi lapangan (wawancara, dan brainstorming), dilanjutkan dengan desk study sebagai langkah proses analisis mendalam dengan workshop terbatas dengan para stakeholder. Langkah-langkah penelitian sebagai berikut ini:

1. Studi Lapangan

Melakukan studi lapangan, yaitu melakukan pengamatan langsung terhadap kegiatan-kegiatan yang berhubungan dengan proses pergudangan, kemudian mulai mencatat aktivitas pergudangan berdasarkan alur produk. Semua informasi dicatat dan dianalisa untuk kemudian membuat proses bisnis pergudangan.

2. Studi Pustaka

Setelah mengamati kegiatan-kegiatan yang terjadi ditempat pengamatan dan merumuskan masalah yang terjadi, hal selanjutnya yang harus dilakukan yaitu mencari data-data, teori-teori dan metode yang relevan (Studi Pustaka) untuk mengelola hasil pengamatan agar menjadi suatu pemecahan masalah yang baik untuk pihak terkait.

3. Perumusan Masalah

Setelah melakukan Studi Pendahuluan, langkah selanjutnya adalah merumuskan masalah yang terjadi ditempat pengamatan dan memfokuskan pada satu masalah yang akan dicari pemecahan masalahnya. Perumusan masalah ini akan menentukan metode yang akan digunakan.

4. Menetapkan Tujuan Penelitian

Tujuan dilakukan penelitian yaitu untuk mempelajari proses bisnis pergudangan di suatu industri, kemudian merancang proses bisnis dan membuat prototype dari aplikasi warehouse management 
system.

5. Menentukan Metode

Untuk mencari Pemecahan Masalah yang terjadi, harus menentukan metode yang akan digunakan. Berdasarkan studi pustaka, apabila metode yang telah dipilih tidak sesuai dengan rencana pemecahan masalah yang akan dilakukan maka akan kembali kelangkah studi pustaka lagi guna menemukan metode yang sesuai. Adapun metode yang digunakan untuk memecahkan masalah diatas adalah metode FSN Analysis.

6. Pengumpulan Data

Setelah melakukan studi lapangan, langkah selanjutnya adalah mengumpulkan data. Kegiatan yang dilakukan yaitu penerimaan barang, pengakurasian barang antara system dan physics actual barang.

7. Pengolahan Data

Setelah data-data yang didapat dari perusahaan baik berupa data primer, maka langkah selanjutnya adalah tahap pengolahan.

8. Analisis Hasil Pengolahan Data

Melakukan analisis terhadap hasil yang didapat dari pengolahan data. Hasil pengolahan data akan menunjukan kebijakan yang seharusnya dilakukan oleh perusahaan. Jika ada yang tidak sesuai, maka akan dibuat solusinya.

\section{Hasil dan Pembahasan}

\subsection{Proses Bisnis Existing}

UKM online Addorable Project telah memiliki gudang baru yang berfungsi sebagai tempat penyimpanan seluruh produk yang akan dijual kepada pelanggan. Gudang ini merupakan gudang baru yang baru difungsikan dan telah menjalankan kegiatan inbound outbound produk yang dikelola.

Aktivitas pergudangan dimulai dari penerimaan produk dari berbagai vendor barang yang dijual seperti sepatu, ketika produk dari vendor diterima, pihak gudang melakukan aktivitas pemindahan barang dari moda transportasi ke area penempatan sementara (staging area) dan disaat yang bersamaan melakukan pengecekan antara fisik dengan dokumen pengiriman barang oleh operator gudang bagian inbound. Setelah barang diletakkan di staging area, bagian QC (Quality Control) akan melakukan pemeriksaan terkait kualitas setiap barangnya, dan menentukan apakah barang masuk dalam kategori diterima atau ditolak. Produk yang ditolak akan dikembalikan kepada vendor (retur) dan produk yang diterima dipindahkan ke area peyimpanan.

Kegiatan pemindahan produk dari staging area ke area penyimpanan, dilakukan secara random diletakkan disetiap rack yang kosong oleh operator gudang dengan mencatat setiap produk berdasarkan bin location atau slotnya pada log book kemudian diinput pada Microsoft excel oleh admin gudang. Produk-produk yang telah disimpan pada area penyimpanan baru bisa keluar ketika ada order dari pelanggan. Pelanggan melakukan transaksi melalui dua platform yaitu marketplace dan media website adorable dan whatssap. Ketika pelanggan sudah menyelesaikan kegiatan transaksi hingga pembayaran. Maka informasi akan masuk ke gudang adorable untuk kemudia dilakukan proses order oleh admin gudang. Lalu admin gudang akan memberikan form order kepada operator outbound untuk melakukan pengambilan barang atau yang disebut picking order. Operator outbound akan mengawali kegiatan dengan mengecek form order untuk melihat informasi yang berada pada dokumen ini seperti nama pelanggan, produk yang dipesan dan lokasi produk pada rack. Setelah produk di ambil, operator memindahkan produk ke area QC outbound untuk dilakukan pemeriksaan terkait kualitas barang. Jika barang telah sesuai standar kualitas maka akan langsung dilakukan pengemasan dan menempelkan resi yang berisikan alamat tujuan pelanggan. Terakhir, operator outbound menyerahkan produk kepada kurir.

\subsection{Proses Bisnis Usulan}

Penelitian ini merancang sistem informasi gudang yang dapat membantu seluruh aktivitas pergudangan seperti perancangan yang digambarkan pada gambar berikut 


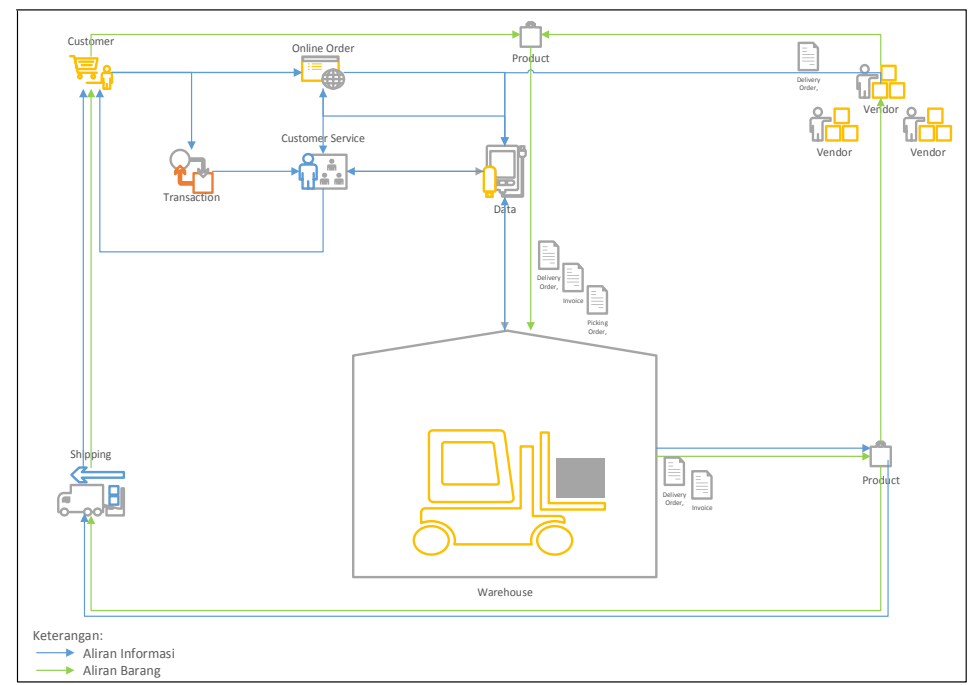

Gambar 1. Aliran Sistem Informasi

Diawali dari vendor yang mengirim barang dan dokumen pengiriman (Delivery Order) ke gudang adorable, data vendor ini kemudian akan menjadi referensi dokumen pengiriman barang (Delivery Order) yang digunakan untuk mencocokan fisik barang dengan dokumen pengiriman barang oleh operator inbound. Selanjutnya pada aktivitas penerimaan barang, operator inbound menginput data produk yang diterima berdasarkan nama vendor, nama produk, ukuran, kuantitas dan varian dengan melakukan proses scanning barcode.

Setelah barang diterima selanjutnya bagian $Q C$ (Quality Control) melakukan pemeriksaan terkait kualitas produk apakah produk tersebut masuk dalam kategori produk diterima atau produk ditolak. Jika ada produk ditolak, maka admin gudang melakukan input kedalam sistem dengan memberikan status ditolak pada dokumen Delivery Order. Sedangkan produk yang diterima akan di berikan status diterima dilanjutkan dengan penyimpanan produk oleh operator inbound. Namun sebelum operator inbound menyimpan barang, sistem akan merekomendasikan kelompak rack. Mekanisme yang dibuat, sistem akan melakukan generate produk pada satuan waktu tertentu kemudian mengkategorikan produk yang dikelola menjadi tiga kelompok; yaitu fast moving produk, slow moving produk, dan non moving produk. Hal ini berkaitan dengan penentuan penempatan barang di rack, rack yang dikhususkan bagi fast moving diletakkan dekat dengan area pintu in/out sedangkan slow moving diletakkan berdekatan dengan pintu in/out namun tidak sedekat fast moving dan non moving berjauhan dengan pintu in/out. Dalam kegiatan mengelompokkannya dibuat persentase FSN analysis.

Setelah dilakukan proses FSN analysis kemudian operator inbound akan menyimpan produk pada rack yang telah ditentukan, dan kembali melakukan scanning barcode pada produk dan rack (bin location) untuk menyimpan data terkait penempatan produk pada bin location.

Kegiatan selanjutnya, adalah picking order dengan mengacu kepada form order dari pelanggan yang dicetak oleh admin gudang. Dokumen ini memberikan informasi terkait nama pelanggan, nama produk, varian, ukuran dan lokasi barang pada area storage. Setelah form order dicetak, operator outbound akan melakukan pengambilan barang sesuai dengan produk dan lokasi yang tertulis pada masing-masing form order. Pada kegiatan pengambilan barang ini, operator outbound melakukan scanning barcode pada produk dan rack (bin location), ketika proses ini dilakukan maka status akan berubah menjadi "proses". Selanjutnya produk dipindahkan ke area QC Outbound untuk dilakukan pemeriksaan kualitas, jika ditemui kerusakan pada produk, maka produk akan discan dan status menjadi "return" lalu operator outbound akan mengganti produk yang sama namun sku berbeda dan cara pengambilan yang sama dengan picking order. Di sisi lain, jika produk lolos kualitas maka QC Outbound akan melakukan scanning dengan status "OK", maka pada saat yang sama akan mengubah status persediaan atau stock di gudang menjadi berkurang. Terakhir produk akan di kemas dan diberikan kepada kurir untuk di antar kepada pelanggan. 


\subsection{Pengumpulan Data}

Data yang digunakan pada penelitian ini didapat dari hasil observasi kepada UKM, pengumpulan data berupa; nama barang, persediaan awal, penerimaan, dan pengeluaran. Terdapat delapan produk yang di analisis selama satu tahun dimulai dari periode Juni 2019 hingga Mei 2020.

Tabel 1. Data Persediaan Item Oxford

\begin{tabular}{ccccc}
\hline & \multicolumn{4}{c}{ Item OXFORD } \\
\cline { 2 - 5 } Periode & Persediaan Awal & Penerimaan & Pengeluaran & Persediaan akhir \\
\hline Jun-19 & 285 & 150 & 46 & 389 \\
Jul-19 & 389 & 150 & 80 & 459 \\
Aug-19 & 459 & 150 & 119 & 490 \\
Sep-19 & 490 & 150 & 91 & 549 \\
Oct-19 & 549 & 150 & 97 & 602 \\
Nov-19 & 602 & 150 & 92 & 660 \\
Dec-19 & 660 & 150 & 89 & 721 \\
Jan-20 & 721 & 150 & 207 & 664 \\
Feb-20 & 664 & 150 & 180 & 634 \\
Mar-20 & 634 & 150 & 439 & 345 \\
Apr-20 & 345 & 150 & 176 & 319 \\
May-20 & 319 & 150 & 469 & 0 \\
\hline Total & $\mathbf{6 1 1 7}$ & $\mathbf{1 8 0 0}$ & $\mathbf{2 0 8 5}$ & $\mathbf{5 8 3 2}$ \\
\hline
\end{tabular}

Tabel 2. Data Persediaan Item Boots

\begin{tabular}{ccccc}
\hline \multirow{2}{*}{ Periode } & \multicolumn{4}{c}{ Item BOOTS } \\
\cline { 2 - 5 } & Persediaan Awal & Penerimaan & Pengeluaran & Persediaan akhir \\
\hline Jun-19 & 500 & 700 & 541 & 659 \\
Jul-19 & 659 & 700 & 291 & 1068 \\
Aug-19 & 1068 & 700 & 738 & 1030 \\
Sep-19 & 1030 & 700 & 693 & 1037 \\
Oct-19 & 1037 & 700 & 982 & 755 \\
Nov-19 & 755 & 700 & 676 & 779 \\
Dec-19 & 779 & 700 & 630 & 849 \\
Jan-20 & 849 & 700 & 593 & 956 \\
Feb-20 & 956 & 700 & 618 & 1038 \\
Mar-20 & 1038 & 700 & 537 & 1201 \\
Apr-20 & 1201 & 700 & 511 & 1390 \\
May-20 & 1390 & 700 & 1894 & 196 \\
\hline Total & $\mathbf{1 1 2 6 2}$ & $\mathbf{8 4 0 0}$ & $\mathbf{8 7 0 4}$ & $\mathbf{1 0 9 5 8}$ \\
\hline
\end{tabular}

Tabel 3. Data Persediaan Item Flatshoes

\begin{tabular}{ccccc}
\hline \multirow{2}{*}{ Periode } & \multicolumn{4}{c}{ Item FLATSHOES } \\
\cline { 2 - 5 } & Persediaan Awal & Penerimaan & Pengeluaran & Persediaan akhir \\
\hline Jun-19 & 1723 & 3000 & 1147 & 3576 \\
Jul-19 & 3576 & 3000 & 1686 & 4890 \\
Aug-19 & 4890 & 3000 & 1845 & 6045 \\
Sep-19 & 6045 & 3000 & 2239 & 6806 \\
Oct-19 & 6806 & 3000 & 2563 & 7243 \\
Nov-19 & 7243 & 3000 & 2110 & 8133
\end{tabular}




\begin{tabular}{ccccc} 
Dec-19 & 8133 & 3000 & 3423 & 7710 \\
Jan-20 & 7710 & 3000 & 3356 & 7354 \\
Feb-20 & 7354 & 3000 & 3075 & 7279 \\
Mar-20 & 7279 & 3000 & 2763 & 7516 \\
Apr-20 & 7516 & 3000 & 2577 & 7939 \\
May-20 & 7939 & 3000 & 5850 & 5089 \\
\hline Total & $\mathbf{7 6 2 1 4}$ & $\mathbf{3 6 0 0 0}$ & $\mathbf{3 2 6 3 4}$ & $\mathbf{7 9 5 8 0}$ \\
\hline
\end{tabular}

Tabel 4. Data Persediaan Item Sneakers

\begin{tabular}{ccccc}
\hline \multirow{2}{*}{ Periode } & \multicolumn{4}{c}{ Item SNEAKERS } \\
\cline { 2 - 5 } & Persediaan Awal & Penerimaan & Pengeluaran & Persediaan akhir \\
\hline Jun-19 & 3215 & 5000 & 3077 & 5138 \\
Jul-19 & 5138 & 5000 & 3902 & 6236 \\
Aug-19 & 6236 & 5000 & 4760 & 6476 \\
Sep-19 & 6476 & 5000 & 4650 & 6826 \\
Oct-19 & 6826 & 5000 & 5417 & 6409 \\
Nov-19 & 6409 & 5000 & 4722 & 6687 \\
Dec-19 & 6687 & 5000 & 6738 & 4949 \\
Jan-20 & 4949 & 5000 & 5238 & 4711 \\
Feb-20 & 4711 & 5000 & 5863 & 3848 \\
Mar-20 & 3848 & 5000 & 5499 & 3349 \\
Apr-20 & 3349 & 5000 & 3461 & 4888 \\
May-20 & 4888 & 5000 & 7296 & 2592 \\
\hline Total & $\mathbf{6 2 7 3 2}$ & $\mathbf{6 0 0 0 0}$ & $\mathbf{6 0 6 2 3}$ & $\mathbf{6 2 1 0 9}$ \\
\hline
\end{tabular}

Tabel 5. Data Persediaan Item Heels

\begin{tabular}{ccccc}
\hline \multirow{2}{*}{ Periode } & \multicolumn{4}{c}{ Item HEELS } \\
\cline { 2 - 5 } & Persediaan Awal & Penerimaan & Pengeluaran & Persediaan akhir \\
\hline Jun-19 & 3245 & 3000 & 1905 & 4340 \\
Jul-19 & 4340 & 3000 & 2564 & 4776 \\
Aug-19 & 4776 & 3000 & 2816 & 4960 \\
Sep-19 & 4960 & 3000 & 2864 & 5096 \\
Oct-19 & 5096 & 3000 & 3232 & 4864 \\
Nov-19 & 4864 & 3000 & 3418 & 4446 \\
Dec-19 & 4446 & 3000 & 3628 & 3818 \\
Jan-20 & 3818 & 3000 & 3858 & 2960 \\
Feb-20 & 2960 & 3000 & 3324 & 2636 \\
Mar-20 & 2636 & 3000 & 3275 & 2361 \\
Apr-20 & 2361 & 3000 & 2284 & 3077 \\
May-20 & 3077 & 3000 & 4892 & 1185 \\
\hline Total & $\mathbf{4 6 5 7 9}$ & $\mathbf{3 6 0 0 0}$ & $\mathbf{3 8 0 6 0}$ & $\mathbf{4 4 5 1 9}$ \\
\hline
\end{tabular}

Tabel 6. Data Persediaan Item Platform

\begin{tabular}{ccccc}
\hline \multirow{2}{*}{ Periode } & \multicolumn{4}{c}{ Item PLATFORM } \\
\cline { 2 - 5 } & Persediaan Awal & Penerimaan & Pengeluaran & Persediaan akhir \\
\hline Jun-19 & 1240 & 1200 & 773 & 1667 \\
Jul-19 & 1667 & 1200 & 816 & 2051 \\
Aug-19 & 2051 & 1200 & 913 & 2338 \\
Sep-19 & 2338 & 1200 & 1214 & 2324 \\
Oct-19 & 2324 & 1200 & 1250 & 2274 \\
Nov-19 & 2274 & 1200 & 921 & 2553
\end{tabular}




\begin{tabular}{ccccc} 
Dec-19 & 2553 & 1200 & 1413 & 2340 \\
Jan-20 & 2340 & 1200 & 1101 & 2439 \\
Feb-20 & 2439 & 1200 & 1266 & 2373 \\
Mar-20 & 2373 & 1200 & 1218 & 2355 \\
Apr-20 & 2355 & 1200 & 745 & 2810 \\
May-20 & 2810 & 1200 & 2345 & 1665 \\
\hline Total & $\mathbf{2 6 7 6 4}$ & $\mathbf{1 4 4 0 0}$ & $\mathbf{1 3 9 7 5}$ & $\mathbf{2 7 1 8 9}$ \\
\hline
\end{tabular}

Tabel 7. Data Persediaan Item Sandal

\begin{tabular}{ccccc}
\hline \multirow{2}{*}{ Periode } & \multicolumn{4}{c}{ Item SANDAL } \\
\cline { 2 - 5 } & Persediaan Awal & Penerimaan & Pengeluaran & Persediaan akhir \\
\hline Jun-19 & 1545 & 2000 & 1066 & 2479 \\
Jul-19 & 2479 & 2000 & 1371 & 3108 \\
Aug-19 & 3108 & 2000 & 1615 & 3493 \\
Sep-19 & 3493 & 2000 & 2037 & 3456 \\
Oct-19 & 3456 & 2000 & 1890 & 3566 \\
Nov-19 & 3566 & 2000 & 1999 & 3567 \\
Dec-19 & 3567 & 2000 & 2324 & 3243 \\
Jan-20 & 3243 & 2000 & 1820 & 3423 \\
Feb-20 & 3423 & 2000 & 1887 & 3536 \\
Mar-20 & 3536 & 2000 & 1467 & 4069 \\
Apr-20 & 4069 & 2000 & 1523 & 4546 \\
May-20 & 4546 & 2000 & 5297 & 1249 \\
\hline Total & $\mathbf{4 0 0 3 1}$ & $\mathbf{2 4 0 0 0}$ & $\mathbf{2 4 2 9 6}$ & $\mathbf{3 9 7 3 5}$ \\
\hline
\end{tabular}

Tabel 8. Data Persediaan Item Backpack

\begin{tabular}{ccccc}
\hline \multirow{2}{*}{ Periode } & \multicolumn{4}{c}{ Item BACKPACK \& MINI BACKPACK } \\
\cline { 2 - 5 } & Persediaan Awal & Penerimaan & Pengeluaran & Persediaan akhir \\
\hline Jun-19 & 643 & 1000 & 525 & 1118 \\
Jul-19 & 1118 & 1000 & 679 & 1439 \\
Aug-19 & 1439 & 1000 & 654 & 1785 \\
Sep-19 & 1785 & 1000 & 710 & 2075 \\
Oct-19 & 2075 & 1000 & 880 & 2195 \\
Nov-19 & 2195 & 1000 & 1122 & 2073 \\
Dec-19 & 2073 & 1000 & 1377 & 1696 \\
Jan-20 & 1696 & 1000 & 1281 & 1415 \\
Feb-20 & 1415 & 1000 & 1021 & 1394 \\
Mar-20 & 1394 & 1000 & 1237 & 1157 \\
Apr-20 & 1157 & 1000 & 743 & 1414 \\
May-20 & 1414 & 1000 & 2388 & 26 \\
\hline Total & $\mathbf{1 8 4 0 4}$ & $\mathbf{1 2 0 0 0}$ & $\mathbf{1 2 6 1 7}$ & $\mathbf{1 7 7 8 7}$
\end{tabular}

\subsection{Pengkajian Metode FSN Analysis}

Pada tahapan pengkajian ini dilakukan proses penentuan kelompok barang berdasarkan tiga kategori; fast moving, slow moving dan non moving, langkah-langkah pengerjaan analisa menggunakan metode FSN analysis di awali dari perhitungan Turn Over Ratio kemudian mengelompokkan produk yang dianalisa menjadi 3 kelompok yaitu fast moving, slow moving, dan non moving.

Langkah-langkah analisis yang dilakukan adalah sebagai berikut:

a. Menentukan data persediaan produk, dimulai dari data persediaan awal, persediaan masuk, dan pengeluaran produk. Kemudian tahap pengerjaannya sebagai berikut: 
b. Menentukan persediaan awal, merupakan persediaan pada setiap awal periode pengamatan.

c. Menentukan persediaan akhir, merupakan persediaan produk yang tersisa pada setiap akhir periode pengamatan. Persediaan awal didapat dari persediaan produk yang tersisa di akhir periode sebelumnya. Jumlah persediaan akhir dihitung menggunakan rumus:

$$
P a k=P a w+P m s-P p k
$$

dimana: Pak merupakan Persediaan akhir, lalu Paw merupakan Persediaan awal, dan Pms adalah barang masuk, terakhir Ppk merupakan barang yang dipakai

d. Menghitung nilai rata-rata persediaan, merupakan nilai rata-rata persediaan produk pada setiap periode pengamatan. Nilai rata-rata persediaan dihitung menggunakan rumus:

$$
\text { Prt }=\frac{\text { Paw }+ \text { Pak }}{2}
$$

dimana: Prt adalah Persediaan Rata-rata

e. Menghitung Turn Over Ratio (TOR) parsial, merupakan perputaran persediaan setiap periode berjalan. Nilai TOR parsial dihitung menggunakan rumus:

$$
\text { TORp }=\frac{\text { Pmk }}{\text { Prt }}
$$

dimana: TORp merupakan Perputaran persediaan parsial selama periode pengamatan, dan Pmk adalah pemakaian barang selama periode pengamatan

f. Menghitung lamanya waktu penyimpanan, adalah waktu rata-rata yang dialami setiap produk untuk mengalami penyimpanan di gudang. Lama waktu penyimpanan barang dapat dihitung menggunakan rumus:

$$
W s p=\frac{7 h p}{T O R}
$$

dimana: Wsp adalah Lamanya waktu penyimpanan, dan Jhp merupakan Jumlah hari selama periode pengamatan

g. Menghitung turn over ratio (TOR), merupakan rasio perputaran persediaan setiap selama satu tahun. Nilai TOR dapat dihitung dengan rumus:

$$
T O R=\frac{\text { ght }}{W s p}
$$

dimana:TOR adalah Perputaran persediaan selama satu tahun dan Jht adalah Jumlah hari selama satu tahun

Pengelompokkan barang dengan FSN Analysis (Fast, Slow, and Non-moving) berdasarkan TOR, dengan kriteria sebagai berikut [10]:

Urutkan data berdasarkan nilai TOR yang tertinggi hingga yang terendah.

Menentukan klasifikasi F (TOR $>3)$, S $(3 \leq$ TOR $\leq 1)$, N $($ TOR $<1)[10]$.

Langkah-langkah pengolahan data yang yang pertama adalah menentukan persediaan awal, yang didapat dari awal setiap periode pengamatan periode Juni 2019 hingga Mei 2020, dapat dilihat pada tabel 1 s.d 8, kemudian menentukan persediaan akhir yang merupakan sisa stok barang di setiap akhir periode pengamatan, kemudian akan menjadi persediaan pada awal periode berikutnya. Persediaan akhir ini dapat dihitung dengan persamaan (1), lalu hasilnya dapat dilihat pada tabel 1 s.d 8.

Menghitung nilai rata-rata persediaan, merupakan nilai dari rata-rata persediaan produk yang terdapat pada setiap periode pengamatan. Nilai rata-rata persediaan ini dapat dihitung dengan persamaan (2), kemudian hasilnya dapat dilihat pada tabel 9. 
Tabel 9. Rata-rata Persediaan

\begin{tabular}{ccccccccc}
\hline & \multicolumn{7}{c}{ Rata-rata Persediaan } \\
\cline { 2 - 9 } Periode & $\begin{array}{c}\text { Item } \\
\text { OXFORD }\end{array}$ & $\begin{array}{c}\text { Item } \\
\text { BOOTS }\end{array}$ & $\begin{array}{c}\text { Item } \\
\text { FLAT } \\
\text { SHOES }\end{array}$ & $\begin{array}{c}\text { Item } \\
\text { SNEAKERS }\end{array}$ & $\begin{array}{c}\text { Item } \\
\text { HEELS }\end{array}$ & $\begin{array}{c}\text { Item } \\
\text { PLATFORM }\end{array}$ & $\begin{array}{c}\text { Item } \\
\text { SANDAL }\end{array}$ & $\begin{array}{c}\text { Item } \\
\text { BACK } \\
\text { PACK }\end{array}$ \\
\hline Jun-19 & 337 & 579,5 & 2649,5 & 4176,5 & 3792,5 & 1453,5 & 2012 & 880,5 \\
Jul-19 & 424 & 863,5 & 4233 & 5687 & 4558 & 1859 & 2793,5 & 1278,5 \\
Aug-19 & 474,5 & 1049 & 5467,5 & 6356 & 4868 & 2194,5 & 3300,5 & 1612 \\
Sep-19 & 519,5 & 1033,5 & 6425,5 & 6651 & 5028 & 2331 & 3474,5 & 1930 \\
Oct-19 & 575,5 & 896 & 7024,5 & 6617,5 & 4980 & 2299 & 3511 & 2135 \\
Nov-19 & 631 & 767 & 7688 & 6548 & 4655 & 2413,5 & 3566,5 & 2134 \\
Dec-19 & 690,5 & 814 & 7921,5 & 5818 & 4132 & 2446,5 & 3405 & 1884,5 \\
Jan-20 & 692,5 & 902,5 & 7532 & 4830 & 3389 & 2389,5 & 3333 & 1555,5 \\
Feb-20 & 649 & 997 & 7316,5 & 4279,5 & 2798 & 2406 & 3479,5 & 1404,5 \\
Mar-20 & 489,5 & 1119,5 & 7397,5 & 3598,5 & 2498,5 & 2364 & 3802,5 & 1275,5 \\
Apr-20 & 332 & 1295,5 & 7727,5 & 4118,5 & 2719 & 2582,5 & 4307,5 & 1285,5 \\
May-20 & 159,5 & 793 & 6514 & 3740 & 2131 & 2237,5 & 2897,5 & 720 \\
Total & 5974,5 & 11110 & 77897 & 62420,5 & 45549 & 26976,5 & 39883 & 18095,5 \\
\hline
\end{tabular}

Menghitung (TOR) turn over ratio parsial, merupakan rasio perputaran stok pada setiap periode berjalan.

Dapat dihitung menggunakan persamaan (3), dan hasilnya dapat dilihat pada tabel 10.

Tabel 10. TOR Partial

\begin{tabular}{|c|c|c|c|c|c|c|c|c|}
\hline \multirow[b]{2}{*}{ Periode } & \multicolumn{8}{|c|}{ TOR Partial } \\
\hline & $\begin{array}{c}\text { Item } \\
\text { OXFORD }\end{array}$ & $\begin{array}{c}\text { Item } \\
\text { BOOTS }\end{array}$ & $\begin{array}{c}\text { Item } \\
\text { FLAT } \\
\text { SHOES }\end{array}$ & $\begin{array}{c}\text { Item } \\
\text { SNEAKERS }\end{array}$ & $\begin{array}{c}\text { Item } \\
\text { HEELS }\end{array}$ & $\begin{array}{c}\text { Item } \\
\text { PLATFORM }\end{array}$ & $\begin{array}{c}\text { Item } \\
\text { SANDAL }\end{array}$ & $\begin{array}{c}\text { Item } \\
\text { BACK } \\
\text { PACK } \\
\end{array}$ \\
\hline Jun-19 & 0,14 & 0,93 & 0,43 & 0,74 & 0,50 & 0,53 & 0,53 & 0,60 \\
\hline Jul-19 & 0,19 & 0,34 & 0,40 & 0,69 & 0,56 & 0,44 & 0,49 & 0,53 \\
\hline Aug-19 & 0,25 & 0,70 & 0,34 & 0,75 & 0,58 & 0,42 & 0,49 & 0,41 \\
\hline Sep-19 & 0,18 & 0,67 & 0,35 & 0,70 & 0,57 & 0,52 & 0,59 & 0,37 \\
\hline Oct-19 & 0,17 & 1,10 & 0,36 & 0,82 & 0,65 & 0,54 & 0,54 & 0,41 \\
\hline Nov-19 & 0,15 & 0,88 & 0,27 & 0,72 & 0,73 & 0,38 & 0,56 & 0,53 \\
\hline Dec-19 & 0,13 & 0,77 & 0,43 & 1,16 & 0,88 & 0,58 & 0,68 & 0,73 \\
\hline Jan-20 & 0,30 & 0,66 & 0,45 & 1,08 & 1,14 & 0,46 & 0,55 & 0,82 \\
\hline Feb-20 & 0,28 & 0,62 & 0,42 & 1,37 & 1,19 & 0,53 & 0,54 & 0,73 \\
\hline Mar-20 & 0,90 & 0,48 & 0,37 & 1,53 & 1,31 & 0,52 & 0,39 & 0,97 \\
\hline Apr-20 & 0,53 & 0,39 & 0,33 & 0,84 & 0,84 & 0,29 & 0,35 & 0,58 \\
\hline May-20 & 2,94 & 2,39 & 0,90 & 1,95 & 2,30 & 1,05 & 1,83 & 3,32 \\
\hline
\end{tabular}

Menghitung lamanya waktu penyimpanan, yaitu waktu rata-rata yang dialami oleh produk ketika disimpan di gudang hingga produk tersebut keluar. Lamanya waktu penyimpanan setiap produk dapat dihitung menggunakan persamaan (4), kemudian hasilnya dapat dilihat pada tabel 11.

Tabel 11. Waktu Penyimpanan

\begin{tabular}{|c|c|c|c|c|c|c|c|c|}
\hline \multirow[b]{2}{*}{ Periode } & \multicolumn{8}{|c|}{ Wsp (Waktu Penyimpanan) } \\
\hline & $\begin{array}{c}\text { Item } \\
\text { OXFORD }\end{array}$ & $\begin{array}{c}\text { Item } \\
\text { BOOTS }\end{array}$ & $\begin{array}{c}\text { Item } \\
\text { FLAT } \\
\text { SHOES }\end{array}$ & $\begin{array}{c}\text { Item } \\
\text { SNEAKERS }\end{array}$ & $\begin{array}{c}\text { Item } \\
\text { HEELS }\end{array}$ & $\begin{array}{c}\text { Item } \\
\text { PLATFORM }\end{array}$ & $\begin{array}{c}\text { Item } \\
\text { SANDAL }\end{array}$ & $\begin{array}{c}\text { Item } \\
\text { BACK } \\
\text { PACK } \\
\end{array}$ \\
\hline Jun-19 & 183,15 & 26,78 & 57,75 & 33,93 & 49,77 & 47,01 & 47,19 & 41,93 \\
\hline Jul-19 & 143,10 & 80,12 & 67,79 & 39,35 & 48,00 & 61,51 & 55,01 & 50,84 \\
\hline Aug-19 & 115,63 & 41,22 & 85,94 & 38,72 & 50,13 & 69,70 & 59,27 & 71,48 \\
\hline Sep-19 & 142,72 & 37,28 & 71,75 & 35,76 & 43,89 & 48,00 & 42,64 & 67,96 \\
\hline Oct-19 & 160,19 & 24,64 & 74,00 & 32,98 & 41,60 & 49,66 & 50,16 & 65,51 \\
\hline
\end{tabular}




\begin{tabular}{ccccccccc} 
Nov-19 & 178,33 & 29,50 & 94,73 & 36,05 & 35,41 & 68,13 & 46,39 & 49,45 \\
Dec-19 & 201,72 & 33,59 & 60,17 & 22,45 & 29,61 & 45,02 & 38,09 & 35,58 \\
Jan-20 & 90,33 & 41,09 & 60,60 & 24,90 & 23,72 & 58,60 & 49,45 & 32,79 \\
Feb-20 & 90,14 & 40,33 & 59,48 & 18,25 & 21,04 & 47,51 & 46,10 & 34,39 \\
Mar-20 & 28,99 & 54,20 & 69,61 & 17,01 & 19,84 & 50,46 & 67,39 & 26,81 \\
Apr-20 & 49,05 & 65,92 & 77,96 & 30,94 & 30,95 & 90,13 & 73,54 & 44,98 \\
May-20 & 8,84 & 10,89 & 28,95 & 13,33 & 11,33 & 24,81 & 14,22 & 7,84 \\
\hline
\end{tabular}

Menghitung (TOR) turn over ratio, merupakan rasio perputaran persediaan setiap selama satu tahun. TOR dapat dihitung menggunakan persamaan (5), dan hasilnya dapat dilihat pada tabel 12 .

Tabel 12. TOR

\begin{tabular}{ccccccccc}
\hline & \multicolumn{7}{c}{ TOR } \\
\cline { 2 - 9 } Periode & $\begin{array}{c}\text { Item } \\
\text { OXFORD }\end{array}$ & $\begin{array}{c}\text { Item } \\
\text { BOOTS }\end{array}$ & $\begin{array}{c}\text { Item } \\
\text { FLAT } \\
\text { SHOES }\end{array}$ & $\begin{array}{c}\text { Item } \\
\text { SNEAKERS }\end{array}$ & $\begin{array}{c}\text { Item } \\
\text { HEELS }\end{array}$ & $\begin{array}{c}\text { Item } \\
\text { PLATFORM }\end{array}$ & $\begin{array}{c}\text { Item } \\
\text { SANDAL }\end{array}$ & $\begin{array}{c}\text { Item } \\
\text { BACK } \\
\text { PACK }\end{array}$ \\
\hline Jun-19 & 1,99 & 13,63 & 6,32 & 10,76 & 7,33 & 7,76 & 7,74 & 8,71 \\
Jul-19 & 2,55 & 4,56 & 5,38 & 9,28 & 7,60 & 5,93 & 6,63 & 7,18 \\
Aug-19 & 3,16 & 8,85 & 4,25 & 9,43 & 7,28 & 5,24 & 6,16 & 5,11 \\
Sep-19 & 2,56 & 9,79 & 5,09 & 10,21 & 8,32 & 7,60 & 8,56 & 5,37 \\
Oct-19 & 2,28 & 14,82 & 4,93 & 11,07 & 8,77 & 7,35 & 7,28 & 5,57 \\
Nov-19 & 2,05 & 12,37 & 3,85 & 10,12 & 10,31 & 5,36 & 7,87 & 7,38 \\
Dec-19 & 1,81 & 10,87 & 6,07 & 16,26 & 12,33 & 8,11 & 9,58 & 10,26 \\
Jan-20 & 4,04 & 8,88 & 6,02 & 14,66 & 15,39 & 6,23 & 7,38 & 11,13 \\
Feb-20 & 4,05 & 9,05 & 6,14 & 20,00 & 17,34 & 7,68 & 7,92 & 10,61 \\
Mar-20 & 12,59 & 6,73 & 5,24 & 21,45 & 18,40 & 7,23 & 5,42 & 13,61 \\
Apr-20 & 7,44 & 5,54 & 4,68 & 11,80 & 11,79 & 4,05 & 4,96 & 8,11 \\
May-20 & 41,28 & 33,53 & 12,61 & 27,39 & 32,23 & 14,71 & 25,66 & 46,56 \\
\hline
\end{tabular}

Pengelompokkan barang dengan FSN analysis berdasarkan TOR dilihat dari kriteria F (TOR $>3), \mathrm{S}(3 \leq$ TOR $\leq 1)$, N $($ TOR $<1)$. Jika dilihat dari hasil perhitungan TOR pada tabel 12, nilai TOR seluruh produk berada pada TOR > 3, sehingga dapat disimpulkan produk-produk yang di analisa masuk ke dalam kelompok fast moving.

Tabel 13. Data Kelompok Barang

\begin{tabular}{lcccccccc}
\hline \multicolumn{10}{c}{ Data kelompok barang } \\
\hline & Oxford & Boots & Flatshoes & Sneakers & Heels & Platform & Sandal & Backpack \\
\hline Rata-rata Persediaan & 2873 & 2172,5 & 3481 & 2897,5 & 1707 & 3148,5 & 1818,5 & 720 \\
TOR Partial & 9,46 & 18,43 & 6,89 & 8,39 & 23,28 & 5,85 & 6,60 & 17,52 \\
Waktu Simpan & 38,57 & 19,81 & 52,94 & 43,53 & 15,68 & 62,44 & 55,31 & 20,83 \\
TOR & 9,46 & 18,43 & 6,89 & 8,39 & 23,28 & 5,85 & 6,60 & 17,52 \\
\hline Kelompok & F & F & F & F & F & F & F & F \\
\hline
\end{tabular}

\subsection{Perancangan Sistem}

\subsubsection{Perancangan Use Case Diagram}

Pada perancangan use case diagram memperlihatkan proses-proses yang akan berjalan pada sistem. Proses-proses dibagi menjadi tiga bagian utama yaitu :

1. Pengelolaan data master yang terdiri dari master material, master storage, master customer, dan master vendor.

2. Transaksi yang terdiri dari proses delivery order, goods receipt, customer order dan picking

3. Report untuk menampilkan laporan-laporan dari hasil transaksi. 
Pada proses goods receipt dan picking dilakukan perhitungan menggunakan metode FSN dalam penentuan lokasi tempat penyimpanan barang yang dikirim dari warehouse serta pengambilan barang dari tempat penyimpanan.

Aktor yang berperan pada sistem dibagi menjadi 3 aktor yaitu :

1. Admin berperan sebagai pengelola data master dan transaksi customer order.

2. Operator berperan sebagai pengelola inbound dan outbound.

3. Manager berperan sebagai evaluasi proses berdasarkan report yang di sajikan oleh sistem.

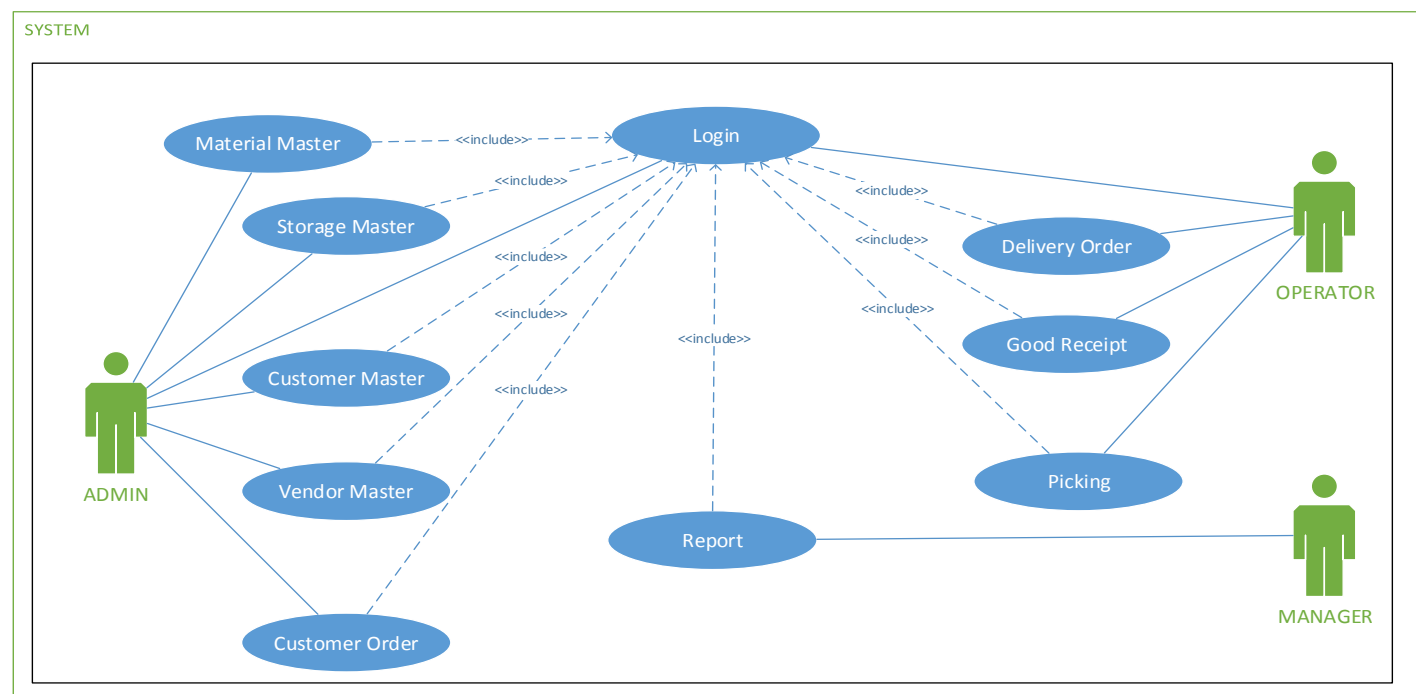

Gambar 2. Use Case Diagram

\subsubsection{Perancangan Class Diagram}

Perancangan class diagram merepresentasikan kumpulan objek yang terkait dengan proses-proses yang akan dilakukan pada sistem. Perancangan ini juga menggambarkan hubungan antar objek dalam berkomunikasi melalui fungsi-fungsi yang terkait dengan objek. Sebagai contohnya pada objek delivery order dibuat akan membutuhkan objek dari vendor dan material, kemudian hasil dari objek delivery order akan dibutuhkan pada saat melakukan goods receipt.

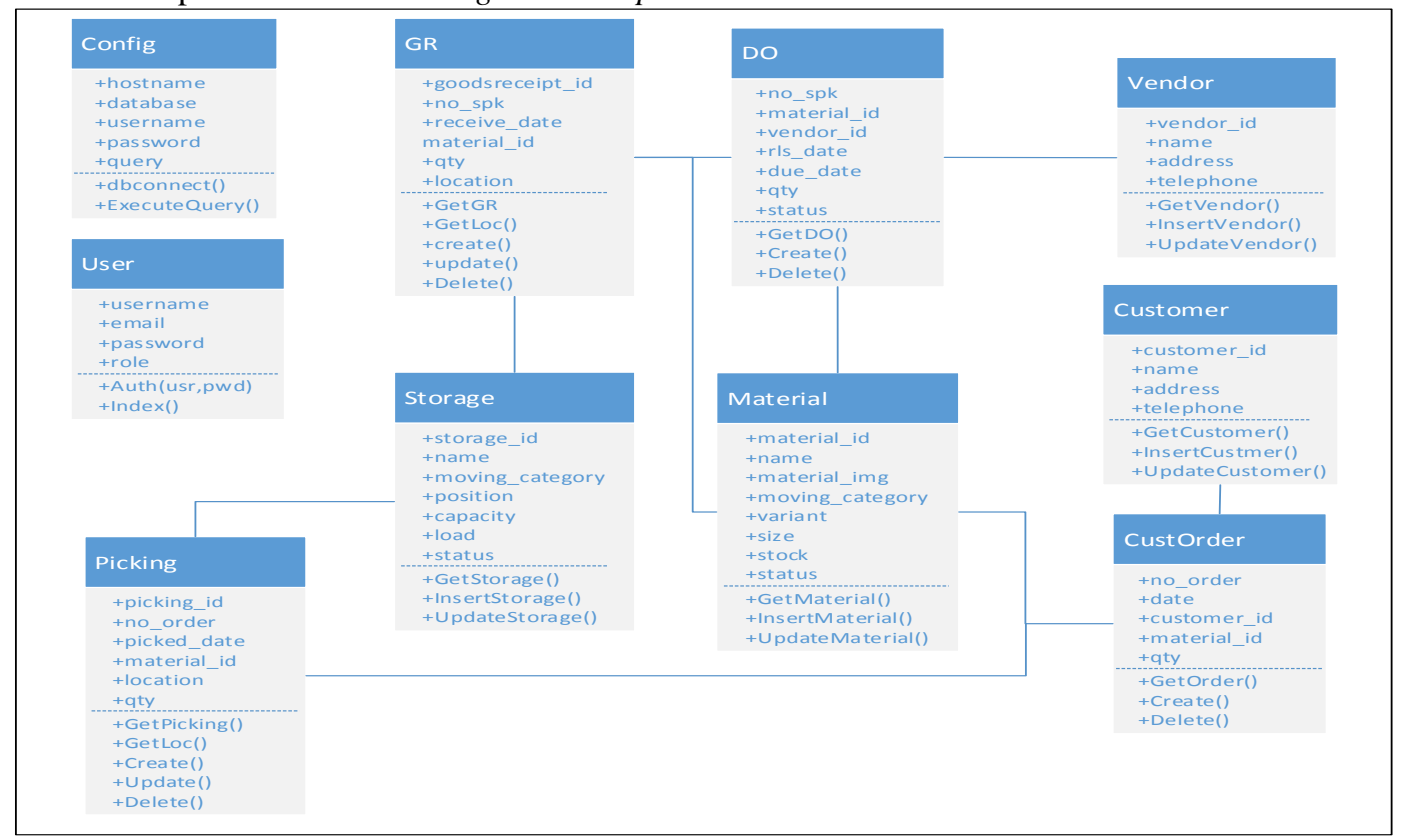

Gambar 3. Class Diagram 


\subsubsection{Perancangan Sequence Diagram}

Perancangan sequence diagram menggambarkan bagaimana objek dalam class diagram berkomunikasi dan memanggil fungsi dalam objek lain untuk melakukan proses yang ada dalam sistem. Berikut sequence diagram dari beberapa proses yang ada pada sistem.

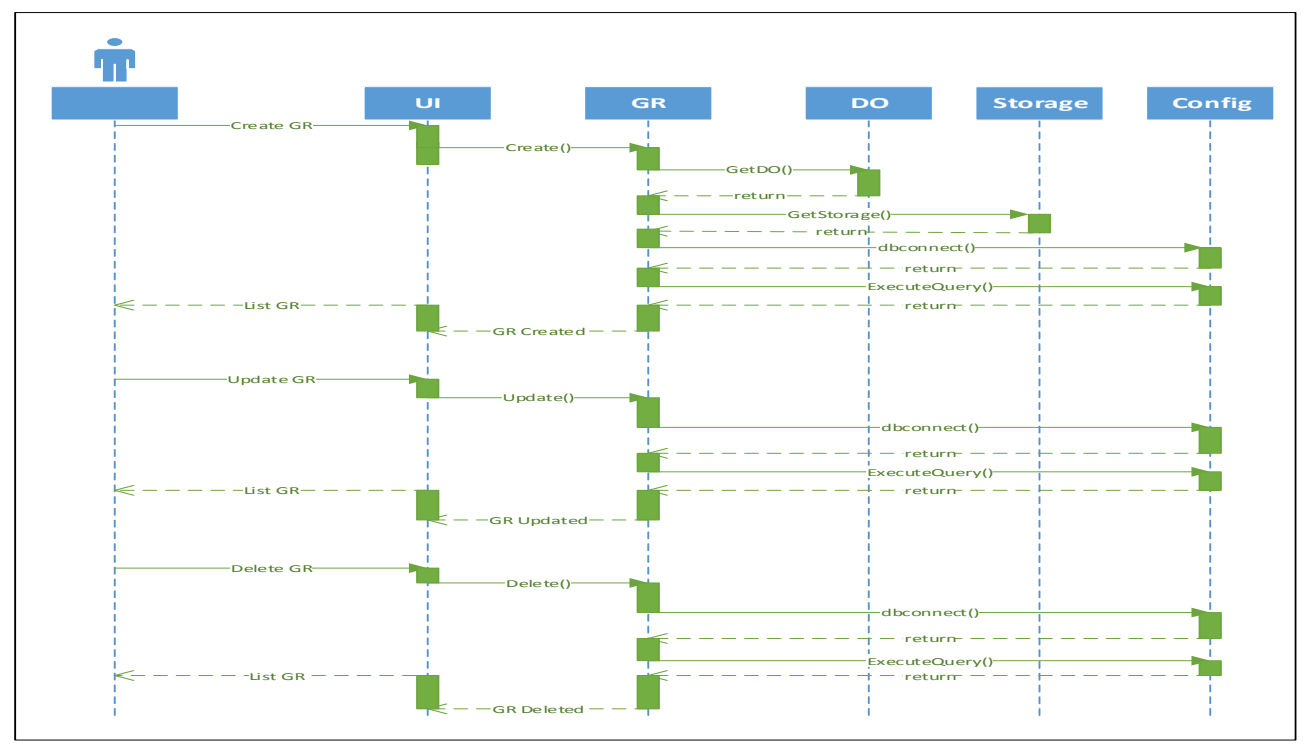

Gambar 4. Goods Receipt Sequence Diagram

Sequence diagram goods receipt menggambarkan fungsi untuk proses penerimaan barang dan rekomondasi alokasi penyimpanan barang yang akan disimpan. Pada fungsi getStorage() digunakan untuk melakukan perhitungan dengan metode FSN Analysis dalam menentukan kategori barang termasuk pada fast moving atau slow moving. Data yang digunakan dalam perhitungan diambil dari storage class dan good receipt class sebelumnya untuk menentukan alokasi barang yang akan disimpan. Output dari sequence ini adalah rekomondasi alokasi storage dari setiap barang.

\subsubsection{Perancangan Database}

Perancangan database menggambarkan struktur data yang digunakan pada sistem sebagai tempat penyimpanan informasi yang diperlukan oleh sistem.

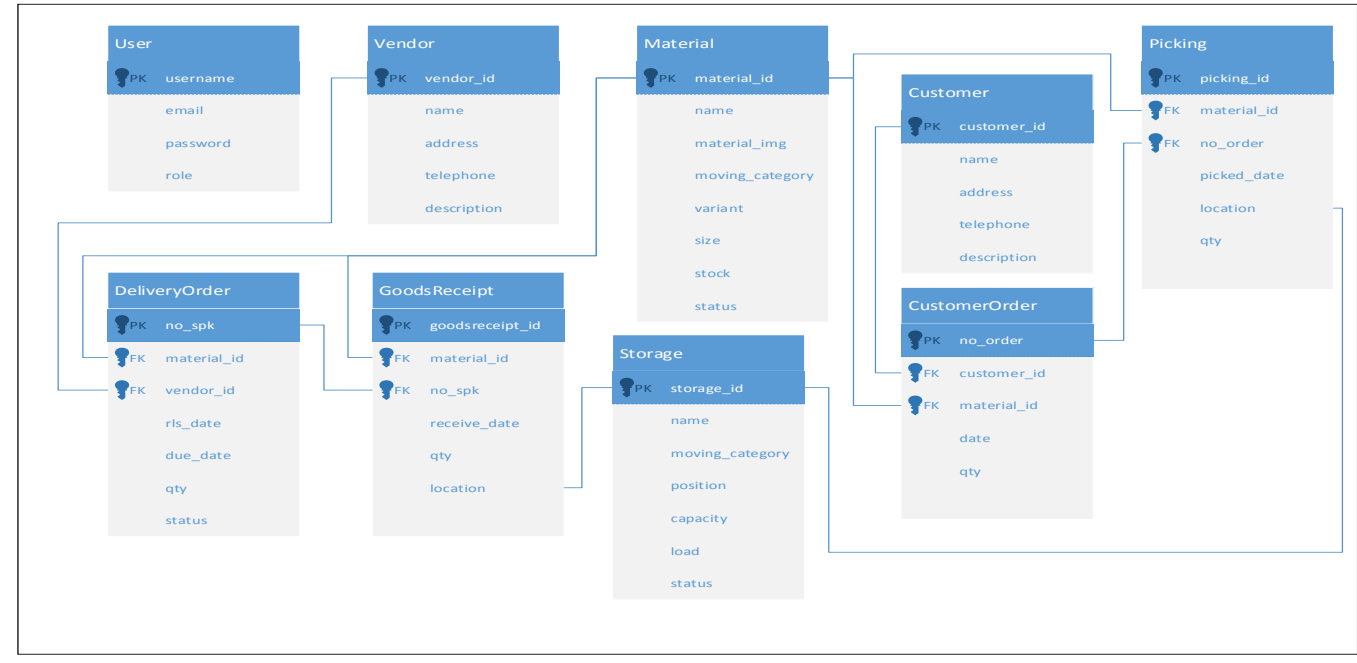

Gambar 5. Rancangan Database 


\subsubsection{Perancangan User Interface}

Perancangan user interface menggambarkan tampilan dari sistem yang digunakan sebagai proses interaksi dari user ke sistem dalam menjalankan proses bisnisnya.

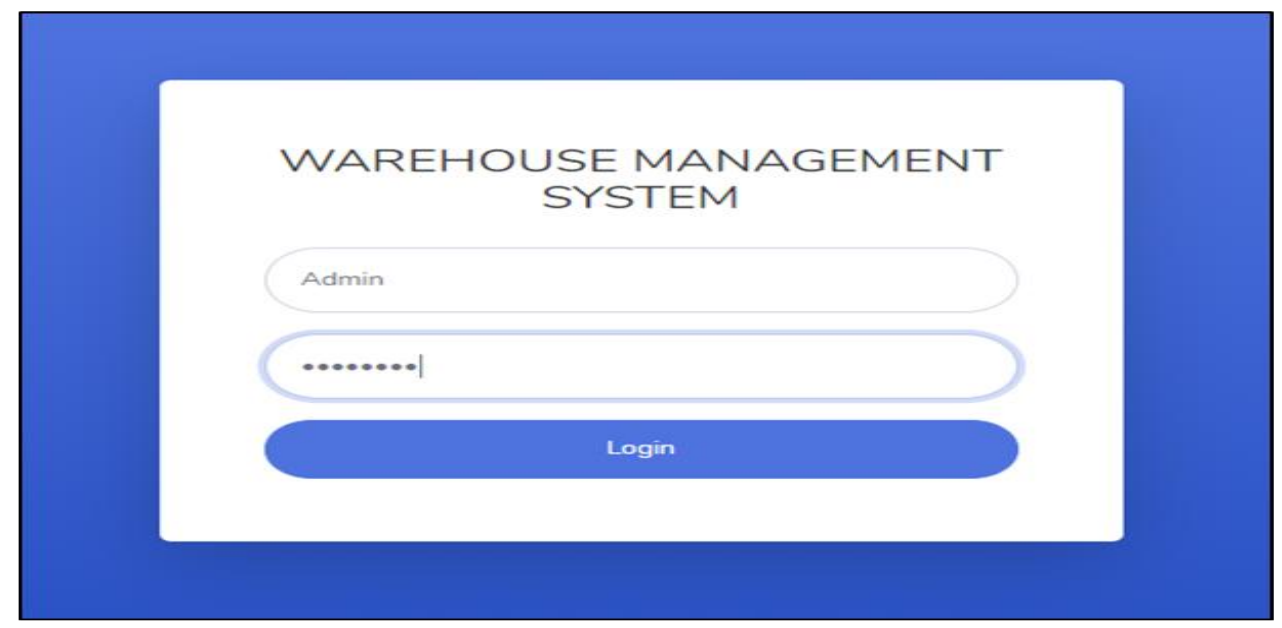

Gambar 6. Login Sistem

Tampilan pada gambar 9 merupakan tampilan awal saat user akses ke sistem. User akan memasukkan username dan password untuk proses autentikasi user sesuai dengan aturan yang berlaku pada sistem.

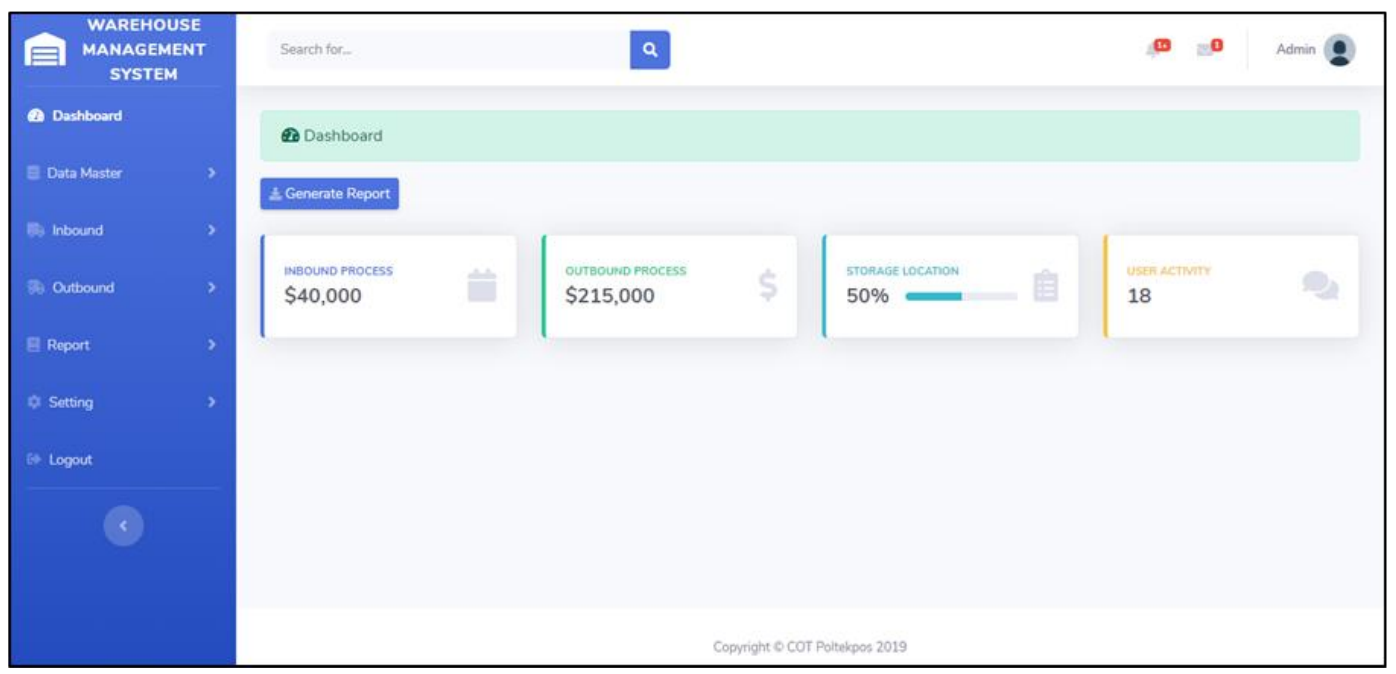

Gambar 7. Halaman Utama Sistem

Tampilan pada gambar halaman utama sistem merupakan tampilan setelah user berhasil login. Menu yang ada pada bagian sebelah kiri akan muncul sesuai dengan aturan dari setiap user. Isi dari halaman utama merupakan tampilan dashboard yang menampilkan rekap dari proses inbound, outbond, kapasitas dari storage dan aktivitas dari user. 


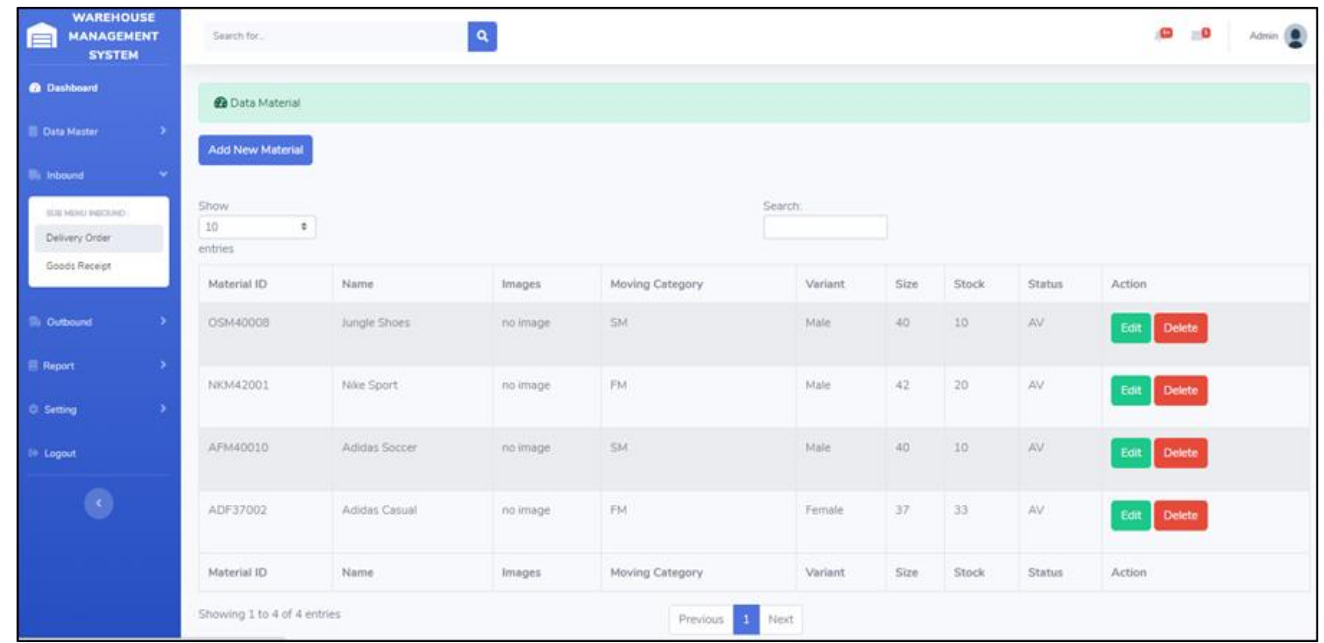

Gambar 8. Tampilan Transaksi Inbound

Tampilan pada transaksi inbound merupakan menu yang digunakan sebagai pengelolaan proses penerimaan material yaitu: Delivery Order dan Goods Receipt. Menu ini digunakan untuk melakukan pengelolaan barang masuk mulai dari menerima dokumen dari Delivery Order dan melakukan pengecekan barang masuk melalui proses Goods Receipt. Bentuk tampilan untuk transaksi inbound secara keseluruhan menampilkan informasi dari transaksi yang dilakukan pada proses pengelolaan barang masuk. Tombol Add New digunakan untuk menambahkan dokumen transaksi inbound dengan parameter dari dokumen yang terkait yaitu Delivery Order. Pada proses Goods Receipt (GR), selain membuat dokumen $G R$ sistem akan memberikan rekomondasi tempat penyimpan barang berdasarkan moving category dari barang yang akan dimasukkan ke dalam warehouse.

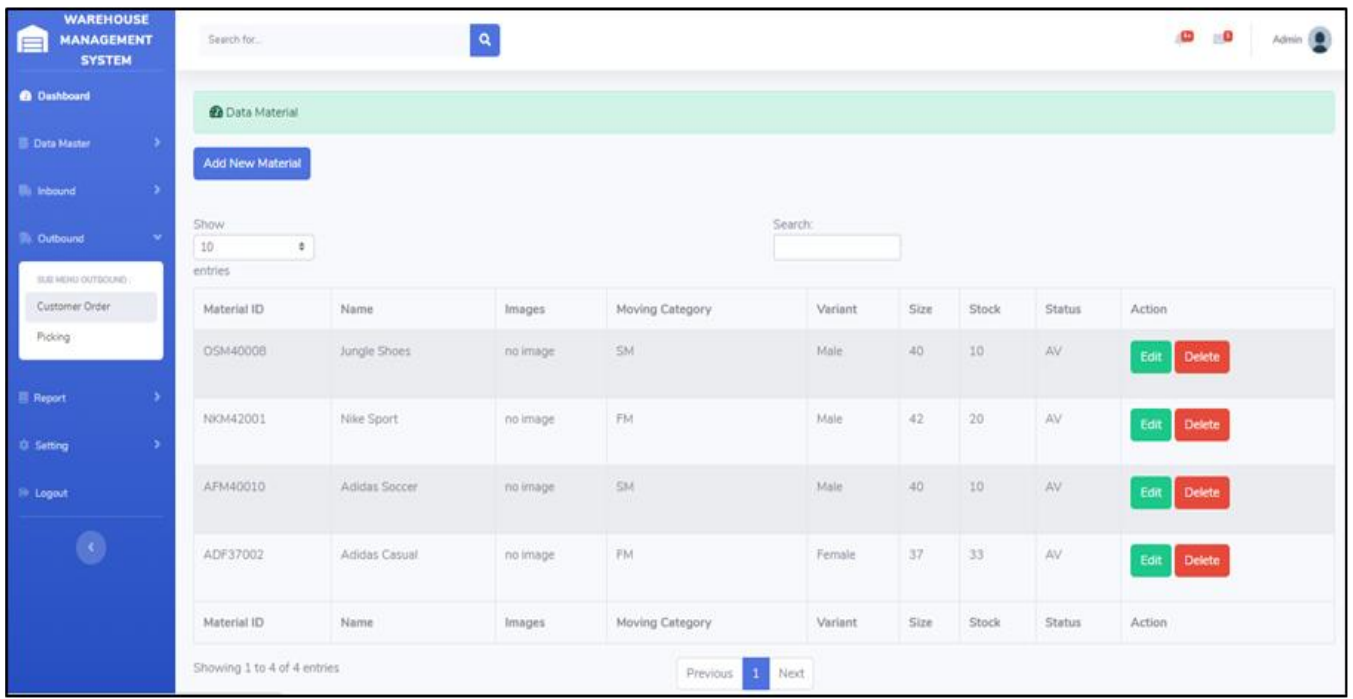

Gambar 9. Transaksi Outbound

Tampilan pada transaksi outbound merupakan menu yang digunakan sebagai pengelolaan proses pengeluaran material yaitu: Customer Order dan Picking. Menu ini digunakan untuk melakukan pengelolaan barang keluar mulai dari membuat dokumen dari Customer Order dan melakukan pengecekan barang keluar melalui proses Picking. Bentuk tampilan untuk transaksi outbound secara keseluruhan menampilkan informasi dari transaksi yang dilakukan pada proses pengelolaan barang keluar. Tombol Add New digunakan untuk menambahkan dokumen transaksi outbound dengan parameter dari dokumen yang terkait yaitu Customer Order. Pada proses Picking, selain membuat dokumen Picking sistem akan memberikan rekomondasi tempat penyimpan barang berdasarkan moving category dari barang yang akan dikeluarkan dari warehouse. 


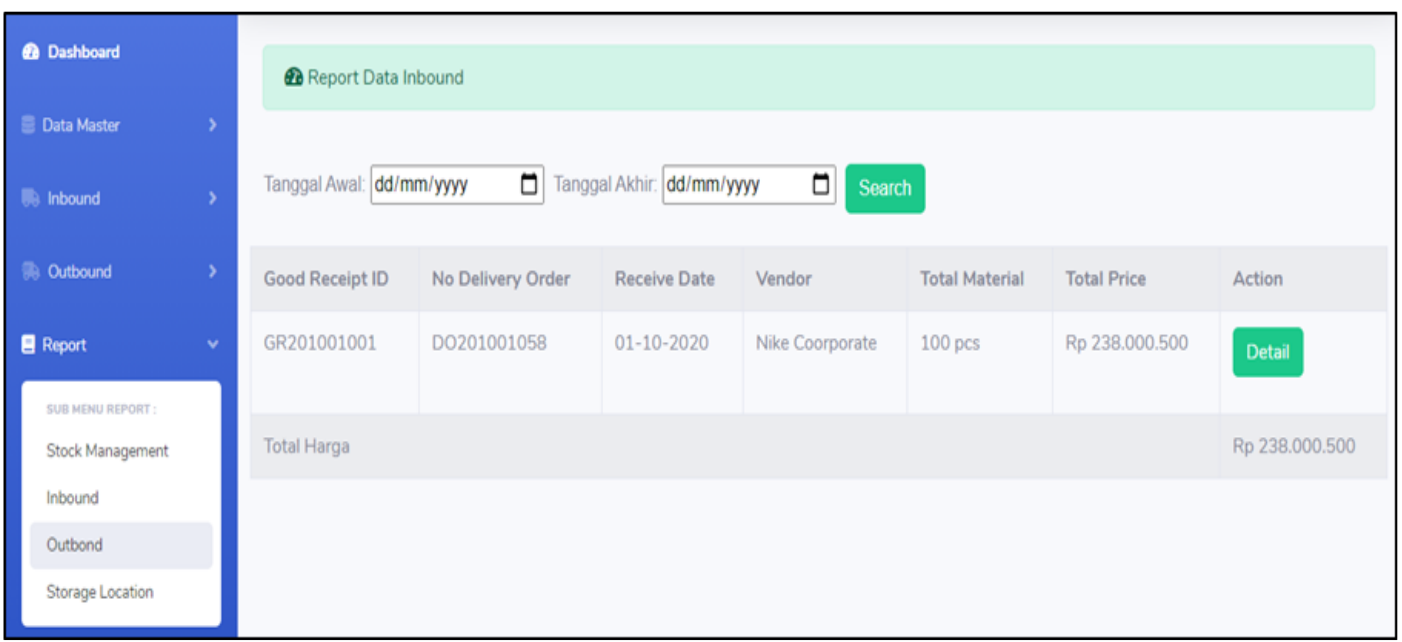

Gambar 10. Tampilan Report

Tampilan report digunakan untuk menyajikan laporan yang dibutuhkan oleh perusahaan. Tampilan report pada sistem terdiri dari 4 bagian yaitu: Stock Management, Inbound, Outbond, dan Storage Location. Secara garis besar isi halaman pada menu report adalah fitur pencarian berdasarkan tanggal awal dan tanggal akhir untuk menampilkan laporan berdasarkan tanggal yang telah ditentukan. Isi dari tabel laporan menunjukkan informasi dari penyajian laporan secara umum dan diakhir tabel memberikan jumlah pendapatan atau pengeluaran dari setiap laporan yang disajikan. Untuk melihat detail dari setiap transaksi yang disajikan pada laporan dapat dilihat dengan cara mengklik tombol detail pada setiap transaksi pada laporan.

\section{Kesimpulan}

Penerapan metode FSN analyisis menghasilkan 3 kelompok produk yaitu kelompok fast, slow dan nonmoving, dilihat dari hasilnya kedelapan produk yang di analisis masuk kedalam kategori fast moving. Oleh karena itu, dengan hasil ini dapat perusahaan dapat memberikan perhatian lebih terhadap barangbarang yang dikelolanya. Penelitian ini menghasilkan prototype sistem informasi pergudangan yang memfasilitasi pengelompokkan barang dengan metode $F S N$ analysis. Dengan dibuatnya rancangan sistem informasi pergudangan ini, dapat mengurangi waktu dalam menyimpan dan mengeluarkan barang, dan level stok barang dapat diawasi secara berkala. Namun penelitian yang dilakukan masih berbentuk prototype, sehingga pada penelitian selanjutnya perlu dilakukan pengembangan aplikasi yang dapat diimplementasikan, dengan memperhatikan keamanan datanya.

\section{Daftar Pustaka}

[1] ArcherPoint, "Warehouse Management in Microsoft Dynamics NAV 2013 Technical White Paper," 2013.

[2] K. Roodbergen and I. Vis, "A model for warehouse layout," IIE Trans. (Institute Ind. Eng., vol. 38, no. 10, pp. 799-811, 2006.

[3] Y. A. Hakim, Z., Setiawan, S., \& Yanatris, "Perancangan Sistem Informasi Penempatan Barang Jadi Pada Departemen Gudang Finish Goods," J. Sisfotek Glob., vol. 7, no. 1, pp. 13-20, 2017.

[4] Y. Amalia, A. Y. Ridwan, and B. Santosa, "Gudang Bahan Baku Pada Divisi Alat Perkeretaapian Pt Pindad ( Persero ) Untuk Mengurangi Waktu Delay,” vol. 2015, no. 4, pp. 48-53, 2015.

[5] M. Fiqran, B. O. Lubis, S. Informasi, and S. Tinggi, "Sistem Informasi Inventory Pada PT. Masterweb Network Jakarta," Sniptek, pp. 177-186, 2015.

[6] O. Irnawati, "Implementasi Metode Waterfall Pada Sistem Informasi Stock Opname," Indones. J. Softw. Eng., vol. 4, no. 1, pp. 79-84, 2018.

[7] L. F. Scavarda, M. Barros, A. J. Scavarda, P. M. Reyes, and P. Jaska, "Warehouse Management System Implementation in a Brazilian Distribution Center," Int. J. Oper. Res. Inf. Syst., vol. 3, no. 2, 
pp. 64-76, 2012.

[8] G. Baruffaldi, R. Accorsi, and R. Manzini, "Warehouse management system customization and information availability in 3pl companies: A decision-support tool," Ind. Manag. Data Syst., vol. 119, no. 2, pp. 251-273, 2019.

[9] M. M. Tambunan, K. Syahputri, I. Rizkya, R. M. Sari, and M. D. Cahyo, "Storage design using Fast moving, Slow moving and Non moving (FSN) analysis," MATEC Web Conf., vol. 197, pp. 1-5, 2018.

[10] D. Devarajan and M. S. Jayamohan, "Stock control in a Chemical Firm: Combined FSN and XYZ Analysis,” Procedia Technol., vol. 24, pp. 562-567, 2016. 